\title{
高职院校涉农专业教育扶贫助力精准扶贫路径探索 一以湖北生物科技职业学院园艺园林学院为例
}

Exploration on the Path of Targeted Poverty Alleviation Through Agriculture-Related Professional Education in Higher Vocational Colleges

— Taking the College of Horticulture and Gardening of Hubei Biotechnology Vocational College as An Example

\section{陈亮 王海萍 王娟 姬胜玫}

Liang Chen Haiping Wang Juan Wang Shengmei Ji

湖北生物科技职业学院

中国・湖北 武汉 430000

Hubei Biotechnology Vocational College,

Wuhan, Hubei, 430000
【摘要】论文介绍了高职院校涉农专业在精准扶贫中的重要地位, 以及涉农专业通过教 育扶贫助力精准扶贫的两大路径: 一是通过提高学生对口就业率; 师生共建帮扶小组开展 社会服务帮助贫困户。

【Abstract】This paper introduces the important role of agriculture-related majors in targeted poverty alleviation in higher vocational colleges, and the two ways for agriculture-related majors to help targeted poverty alleviation through educational poverty alleviation: one is to improve the employment rate of students; Second, teachers and students to jointly help the group to carry out social services to help the poor.

【关键词】高职; 精准扶贫; 涉农专业

【Keywords \higher vocational education; targeted poverty alleviation; agriculture-related majors 【DOI】10.36012/sde.v2i4.1893

\section{1 引言}

中国共产党第十九次全国代表大会政府工作报告中,要 求发挥职业教育在精准扶贫中的重要作用。“扶贫先扶智”, 唯 有“扶智”才是长久之计,必须从“大水漫灌”向“精准扶贫”转 变。数据显示, 没有一技之长无法就业获得稳定的收入是贫困 的主要原因之一[1]。因此, 通过解决就业问题可以从根本上解 决贫困问题。与本科教育相比,职业教育最大的不同在于侧重 技能的培养, 学生毕业后可以快速就业而摆脱贫困。贫困家庭 的孩子通常接受的教育资源也相对贵乏，加之本科院校学费 高于职业院校，因此职业院校中来自贫困家庭的孩子多于本 科院校。可见, 高职院校做好教育扶贫工作显得尤为重要。

高职教育最本质的特征是要促进学生就业。而《2019 年 中国大学生就业报告》中显示, 2018 届大学毕业生的就业率 为 $91.5 \%$, 而农学专业工作与专业相关度最低, 为 $57 \%$ 。该数 据表明农学类专业对口就业率低, 主要原因是:一是学生职业 认同感偏低, 认为农业类相关工作不体面; 二是学生实际所学

【作者简介】陈亮(1986 ), 女, 湖北黄石人, 讲师, 从事农业气象、田 间试验设计与统计、种子加工败藏、生态学等课程的教学研究。
与企业、行业所需, 不一致; 三是学生理论掌握的多, 而实际动 手能力差, 毕业后无法直接上岗。

农业是国之根本, 而全国高职院校中, 涉农专业开设院校 很少。乡村振兴战略实施, 急需大量农业人才。主动融入精准 扶贫, 对接“乡村振兴战略”和农村发展战略, 改善中国农村产 业结构、提高农业科技发展水平, 是高职院校涉农专业的一个 重要使命 ${ }^{[2]}$ 。

因此, 高职院校农学专业实施教育扶贫的关键是帮助学 生就业, 以及通过专业知识帮助贫困户掌握技能实现创收 ${ }^{[3]}$ 。 湖北生物科技职业学院园艺园林学院涉农专业主要有种子生 产与经营专业(省级特色专业)、园艺技术专业(省级骨干专 业)、现代农业技术专业(省级重点扶持专业)等, 通过几年的 努力, 学生的对口就业率大幅提升, 帮扶对象基本脱贫, 主要 措施如下。

\section{2 提高专业对口就业率, 掌握谋生技能} (以种子生产与经营专业为例)

\section{1 加强课程思政, 提高学生使命感和职业认同感}

根据历届高职涉农专业调查中发现，选择涉农专业绝大 部分是因为录取分数或学费较其他专业低, 少数是因为热爱 
农业而报考的,他们的职业认同感普遍偏低。他们的学习基础 一般较其他专业的学生弱, 自律能力差, 纪律观念淡薄。特别 是涉及田间实训时, 怕苦怕累当逃兵的多。因此,农学类专业 课程教学中加强课程思政建设显得尤为重要。

一是结合时政新闻提升学生使命感。在农业专业课程教 学中, 结合最新的有关农业的时政新闻,让学生认识到农业的 重要性 ${ }^{[4]}$ 。讲解国家在农业方面出台的方针政策、对农业补占 项目及力度,让学生意识到农业在中国的重要地位。引入国际 最新的新闻案例, 让学生认识到中国农业发展的水平及与国 外的差距,激发学生斗志。例如,中美贸易战下的种子危机、很 多农作物种子大量依靠进口等,提升学生的使命感。

二是通过著名学者故事提高学生职业认同感。每门学科 都有自身的发展历史进程, 这个过程中离不开无数科学家的 辛勤付出 ${ }^{[5]}$ 。让他们感受这个过程的艰难, 以及现在的发展成 就, 提高职业认同感。例如, 杂交水稻之父袁隆平,他历尽千辛 寻找最佳的雄志败育野生稻, 他 88 岁高龄再创奇迹——亩 盐碱地种水稻解 8000 万人粮食问题。

通过专业课思政教育, 学生学习主动性和积极性较以往 有很大提高。

\section{2 三对接研究,让学生所学及所需}

一是专业设置与产业需求对接。校企合作人才培养目标 与规范。农作物的生产要遵循农作物的生长规律, 种子、化 肥、农药的生产和管理也要受到国家和行业的制约。因此, 掌 握的专业方向和课程建设,也需要联系的行业和企业,使企业 能够充分参与的开发人才培训计划符合该行业的要求, 毕业 生可能会达到“毕业就业”。学院农业专业在成立之初就受到 学院和系的高度重视。在前期充分调研的基础上,与省内多家 大型农业企业共同制定了人才培养方案。在课程设置、实训方 案安排等环节也符合作物生长和企业的要求, 并根据行业要 求不断调整和修改人才培养方案。

二是教学过程与生产过程对接。理论教学与实践教学交替 进行：合作种子企业种子加工最繁忙的时间一般在 11-12 月, 传统教学学生在此时无法到加工工厂一线学习。待有时间再 去时,加工工厂的任务已基本完成, 种子加工的大部分机械也 不再运行。因此, 根据学徒制的弹性学制的要求, 将该专业此 时间段的其他课程前移或滞后, 留出整段的时间便于学生在 企业一线岗位锻炼, 由企业师傅带教。同时, 在 9 月份学习《种 子加工包装与咜运》课程的基础知识,再去企业一线学习, 回
来后教师再进行补充与梳理。

\section{3 开展社会服务,帮助贫困户创收}

一是专业课教师为贫困户提供生产技术支持。根据农时, 定期开展种植技术、病虫害防治技术、农业政策法规等知识培 训及讲座。例如, 园艺技术专业教师为花卉苗木种植户进行技 术指导、制作宣传栏; 为花卉苗木种植户定期举行苗木生产知 识和管理技能的讲座, 赠送相关技术手册、书籍; 种子生产与 经营专业教师为种植专业户举办植物病虫害防治培训班。

二是师生共建一对一帮扶小组。一个小组帮助一户贫困 户解决实际生产问题。教师带领学生深入贫困户, 学生根据自 身所学, 帮助贫困户进行土壤养分测定、配方施肥、苗木修剪、 果树嫁接等工作。帮扶小组收集贫困户日常生产问题,通过讨 论、收集资料、请教老师等方式解决难题，既让学生学以致用， 也解决了贫困户日常种植问题。

三是联合其他专业教师拓展服务范围。联合园林设计专 业教师，对有条件的村庄进行休闲农庄规划，制作设计图纸。 联合市场营销专业教师,开展电商销售农产品的策划和指导。 联合校心理健康服务中心, 开展心理知识讲座,让他们对脱贫 有信心、热爱生活。

\section{4 结语}

就业不仅是贫困人口脱贫的重要方式，也是所有人提高 生活水平实现中国梦的必由之路。因此,就业问题始终摆在职 业教育的首位。通过以上措施,涉农专业学生较以往有了较大 的职业认同感和自豪感, 对口就业率稳定在 $90 \%$ 以上。零过渡 就业让学生有了自信,毕业后还能通过教师开设的网络课程进 行持续性的学习,让学生有了底气。师生共同开展社会服务,既 帮助了贫困户, 又让自身的专业知识得到了巩固和提高。

\section{参考文献}

[1]梁惠婷. 安徽财资职业学院贫困生资助体系的问题与优化对 策研究[D].合肥:安徽大学, 2016 .

[2]陈亮.高职院校《种子加工包装与财运》课程的“三对接”研究 [J].安徽农业科学,2019(1):278-279.

[3] 罗天宽,张小玲,许方程.高职种子生产与经营专业人才培养对 接行业需求的探索与实践[J].职业教育研究,2015(1):75-78.

[4]付艳,张瑜,刘华等.高职院校《发酵技术》课程“三对接”教学模 式的研究与实践[J].黑龙江科技信息,2016 (13):28.

[5]王海萍,王娟等.种子生产与经营专业“六双”订单式人才培养 模式的探索与实践[J].科学种养,2015(2):335-337 